Рекомендована д. фрармац. наук, профр. Т. А. Грошовим

УДК 615.15: 37.018.4

DOI 10.11603/2312-0967.2017.3.7869

\title{
ВПРОВАДЖЕННЯ ДИСТАНЦІЙНОЇ ФОРМИ НАВЧАННЯ У ФАРМАЦЕВТИЧНУ ОСВІТУ (НА ПРИКЛАДІ НАЦІОНАЛЬНОГО ФАРМАЦЕВТИЧНОГО УНІВЕРСИТЕТУ)
}

\author{
(c) Л. В. Галій, Т. М. Серопян \\ Національний фрармацевтичний університет, Харків \\ larisa_galiy@ukr.net
}

\begin{abstract}
Мета роботи. Узагальнення вимог нормативно-правових документів МОН України та визначення методологічних засад впровадження дистанційного навчання у фрармацевтичну освіту.

Матеріали і методи. Системний метод, порівняльний та нормативно-правовий аналіз, метод педагогічного експерименту.

Результати й обговорення. На прикладі Національного фрармацевтичного університету (м. Харків) узагальнено етапи та конкретні заходи щодо виконання вимог нормативно-правових документів МОН України 3 впровадження дистанційного навчання. Описано організаційне, науково-методичне, кадрове, матеріальнотехнічне та інформаційне забезпечення університету. На підставі запропонованих авторами методологічних засад дистанційного навчання розроблено графік навчального процесу та здійснено координацію педагогічного експерименту, у якому взяли участь 63 здобувачі вищої освіти та 17 кафедр університету.

Висновки. Запропоновані та опрацьовані під час педагогічного експерименту методологічні засади дистанційного навчання забезпечують прозорість та постійний контроль як за освітньою діяльністю здобувачів вищої освіти, так і за її супроводженням з боку тьюторів. Досвід впровадження дистанційного навчання у Національному фрармацевтичному університеті (м. Харків) може бути використаний іншими вузами, які забезпечують підготовку спеціалістів фрармації.
\end{abstract}

Ключові слова: дистанційне навчання; фармацевтична освіта; тьютор; педагогічний експеримент.

Вступ. Фармацевтичну освіту в Україні сьогодні можна здобути як за денною (очною та вечірньою), так і за заочною формами. Необхідно зазначити, що традиційна заочна фрорма навчання за спеціальністю «Фармація» останнім часом все більше піддається критиці з боку науковців, громадських організацій та представників фрармацевтичної спільноти $[1,2]$. Причинами такої критики, перш за все, є непрозорість і обмеженість контролю за діями студентів у міжсесійний період та низька вірогідність опанування великих обсягів матеріалу дисциплін у короткі (до 40 днів на рік) терміни сесій. 3 іншого боку, для значної кількості громадян України заочна фрорма навчання $є$ реалізацією їх конституційного права на здобуття вищої освіти.

Враховуючи зазначені аспекти, Національний фармацевтичний університет 3 початку 2012/2013 навчального року розпочав системну діяльність із перетворення застарілої заочної фрорми навчання у найсучаснішу - дистанційну.

Мета роботи - узагальнення вимог нормативноправових документів МОН України та визначення методологічних засад впровадження дистанційного навчання у фрармацевтичну освіту.

Матеріали і методи. Для досягнення поставленої мети використано системний метод, порівняльний та нормативно-правовий аналіз, метод педагогічного експерименту.
Результати й обговорення. Дистанційне навчання, тобто навчання з використанням новітніх педагогічних та інорормаційно-комунікативних технологій, сьогодні достатньо широко розповсюджене у фармацевтичній освіті багатьох країн світу. Так, у Великій Британії пропонується 18 освітніх програм, а у Сполучених Штатах Америки - 21, зокрема в University of Florida - 5 [3-6]. Тривалість та особливості деяких із зазначених освітніх програм наведено в таблиці 1.

В українських вищих навчальних закладах, у тому числі з післядипломної фрармацевтичної освіти, досвід використання дистанційного навчання обмежений.

Нормативно-правовими документами, що регламентують впровадження дистанційної фрорми навчання в освітню діяльність вітчизняних ВНЗ, $€$ «Положення про дистанційне навчання», затверджене наказом МОН України від 25.04.2013 р. № 466 [7] та «Вимоги до ВНЗ, що надають освітні послуги за дистанційною формою навчання з підготовки фахівців за акредитованими напрямами та спеціальностями», що затверджені наказом МOH України від 30.10.2013 р. № 1518 [8].

Заходи щодо виконання вимог зазначених нормативно-правових документів Національним фрармацевтичним університетом (м. Харків) узагальнено у таблиці 2.

ISSN 2312-0967. Фармацевтичний часопис. 2017. № 3 
Таблиця 1. Дистанційні освітні програми, які пропонують університети Великої Британії та США

\begin{tabular}{|c|c|c|c|}
\hline $\begin{array}{c}\text { Назва } \\
\text { університету }\end{array}$ & Освітня програма & $\begin{array}{c}\text { Тривалість, обсяг } \\
\text { кредитів }\end{array}$ & Особливості програми \\
\hline $\begin{array}{c}\text { Keele } \\
\text { University }\end{array}$ & $\begin{array}{c}\text { Maгістр, } \\
\text { Clinical Pharmacy }\end{array}$ & 12 місяців & $\begin{array}{l}\text { Академічні вимоги: здобувачі повинні мати досвід } \\
\text { роботи у лікарняній фрармації протягом 6-12 місяців; } \\
\text { кандидати повинні бути зареєстровані в Генеральній } \\
\text { фармацевтичній раді або її аналогу для закордонних } \\
\text { фармацевтів; } \\
\text { постійна підтримка тьютора }\end{array}$ \\
\hline $\begin{array}{l}\text { The University } \\
\text { of Manchester }\end{array}$ & $\begin{array}{c}\text { Maгістр, } \\
\text { Clinical Pharmacy }\end{array}$ & 36 місяців & $\begin{array}{l}\text { Академічні вимоги: наявність фрармацевтичної освіти, } \\
10 \text { год навчального часу на тиждень; } \\
\text { вибір повністю он-лайн навчання та змішаного, при } \\
\text { змішаному передбачено } 2 \text { очні дні навчання; } \\
\text { програма розподілена на } 3 \text { роки: } 2 \text { роки теоретичне } \\
\text { навчання, 3-й рік - написання магістерської роботи }\end{array}$ \\
\hline $\begin{array}{l}\text { Cardiff } \\
\text { University }\end{array}$ & $\begin{array}{c}\text { Mагістр, } \\
\text { Clinical Pharmacy }\end{array}$ & 36 місяців & $\begin{array}{l}\text { Режим навчання - змішаний; } \\
\text { у перші два роки навчання передбачається практичне } \\
\text { навчання кожні } 3 \text { місяці; } \\
\text { наявність особистого «наставника» - тьютора, до } \\
\text { якого можна звертатися в будь-який час доби }\end{array}$ \\
\hline \multirow{4}{*}{$\begin{array}{l}\text { University of } \\
\text { Florida }\end{array}$} & $\begin{array}{c}\text { Maгістр, } \\
\text { Pharmaceutical } \\
\text { Chemistry Program }\end{array}$ & $\begin{array}{c}32 \text { кредити, може } \\
\text { бути завершена за } \\
1 \text { рік }\end{array}$ & $\begin{array}{l}\text { Програма розпочата в } 2009 \text { р.; } \\
\text { академічні вимоги: працюючі спеціалісти у } \\
\text { фрармацевтичній промисловості або ті, хто бажає } \\
\text { змінити кар'єру; } \\
\begin{array}{l}\text { Вивчають теми, пов'язані } 3 \text { проектуванням та } \\
\text { розробкою лікарських засобів }\end{array}\end{array}$ \\
\hline & $\begin{array}{l}\text { Marictp, } \\
\text { Clinical Toxicology } \\
\text { Program } \\
\end{array}$ & $\begin{array}{c}32 \text { кредити, може } \\
\text { бути завершена за } \\
1 \text { рік }\end{array}$ & $\begin{array}{l}\text { Академічні вимоги: фрармацевти, медичні працівники, } \\
\text { які працюють у закладах невідкладної допомоги, } \\
\text { лікарнях, токсикологічних центрах }\end{array}$ \\
\hline & $\begin{array}{c}\text { Maricтр, } \\
\text { Pharmaceutical } \\
\text { Outcomes \& Policy }\end{array}$ & $\begin{array}{l}30 \text { кредитів, може } \\
\text { бути завершена за } \\
1-2 \text { роки }\end{array}$ & $\begin{array}{l}\text { Вивчається фрармакоекономіка, безпека пацієнтів } \\
\text { у медикаментозному користуванні, регулювання } \\
\text { фрармацевтичної галузі }\end{array}$ \\
\hline & $\begin{array}{l}\text { Maricтр, } \\
\text { Medication Therapy } \\
\text { Management } \\
\text { Program } \\
\end{array}$ & $\begin{array}{l}33 \text { кредити, може } \\
\text { бути завершена за } \\
5 \text { семестрів }\end{array}$ & $\begin{array}{l}\text { Вивчаються основні принципи бізнесу, включно } \\
\text { планування, маркетинг, менеджмент та фрінанси, а } \\
\text { також поглиблене вивчення лікарської терапії }\end{array}$ \\
\hline
\end{tabular}

Таблиця 2. Виконання вимог нормативно-правової бази з впровадження дистанційного навчання Національним фрармацевтичним університетом (станом на 01.06.2017р.)

\begin{tabular}{|c|c|}
\hline Вимоги & Заходи щодо виконання вимог із впровадження дистанційного навчання \\
\hline 1 & 2 \\
\hline 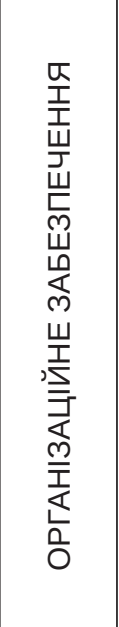 & 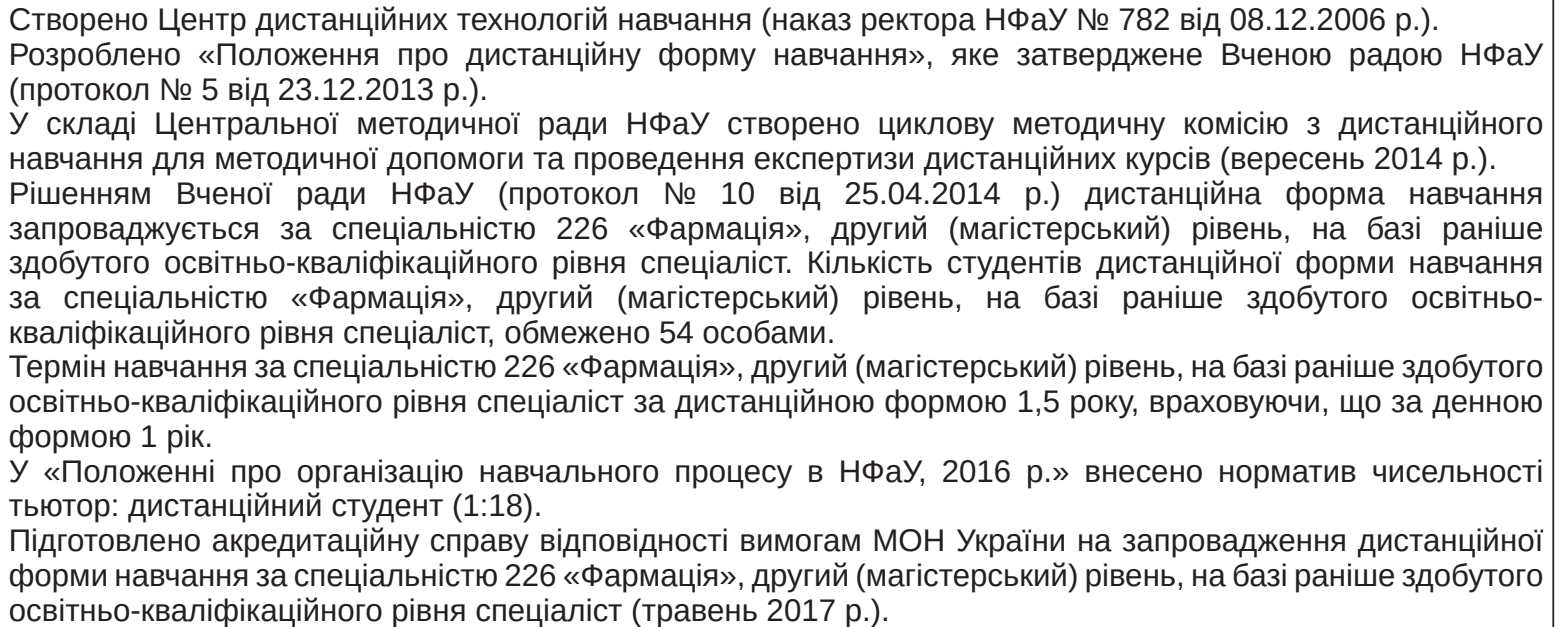 \\
\hline
\end{tabular}

ISSN 2312-0967. Pharmaceutical review. 2017. № 3 
Продовження табл. 2

\begin{tabular}{|c|c|}
\hline 1 & 2 \\
\hline 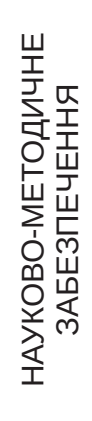 & $\begin{array}{l}\text { озроблено «Положення про експертизу дистанційного курсу у НФаУ» (грудень } 2013 \text { р.). } \\
\text { озроблено та затверджено навчальний план спеціальності } 226 \text { «Фармація», другий (магістерський) } \\
\text { івень, на базі раніше здобутого освітньо-кваліфікаційного рівня спеціаліст, термін навчання 1,5 року, } \\
\text { истанційна фрорма навчання. } \\
\text { атверджено перелік видів навчальних занять та контрольних заходів, що здійснюються очно. За рішенням } \\
\text { ченої ради НФаУ (протокол № } 10 \text { від } 25.04 .2014 \text { р.) підсумкові модульні контролі } 3 \text { усіх дисциплін та } \\
\text { абораторні роботи проводяться виключно в аудиторіях НФаУ. } \\
\text { творено методичні рекомендації щодо розроблення та використання технологій дистанційного навчання } \\
\text { навчальному процесі. } \\
\text { liнімальними критеріями та засобами контролю якості дистанційного навчання в НФаУ визнано } 100 \% \\
\text { иконання вимог МОН України (накази № } 466 \text { та } 1518) \text { Матеріали акредитаційної справи, за результатами } \\
\text { еревірки МОН, будуть розміщені на сайті НФаУ у вільному доступі. }\end{array}$ \\
\hline 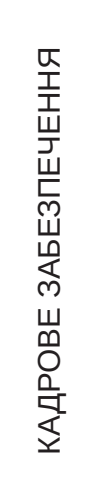 & 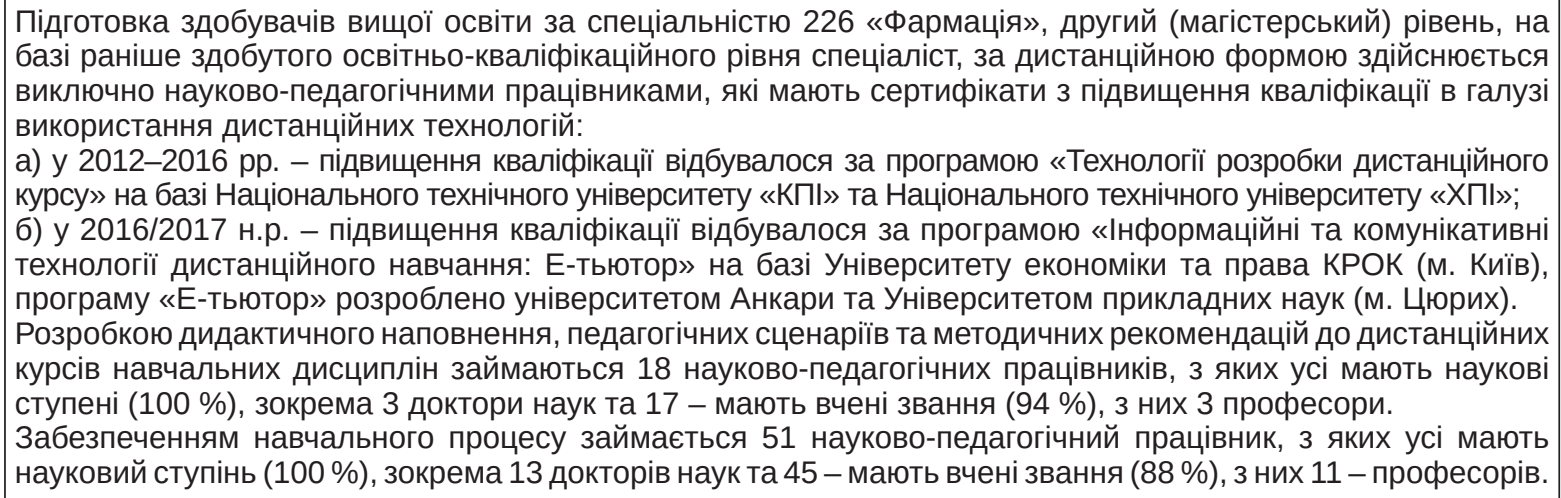 \\
\hline 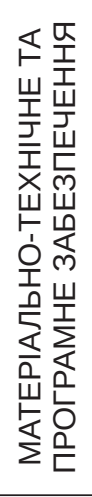 & 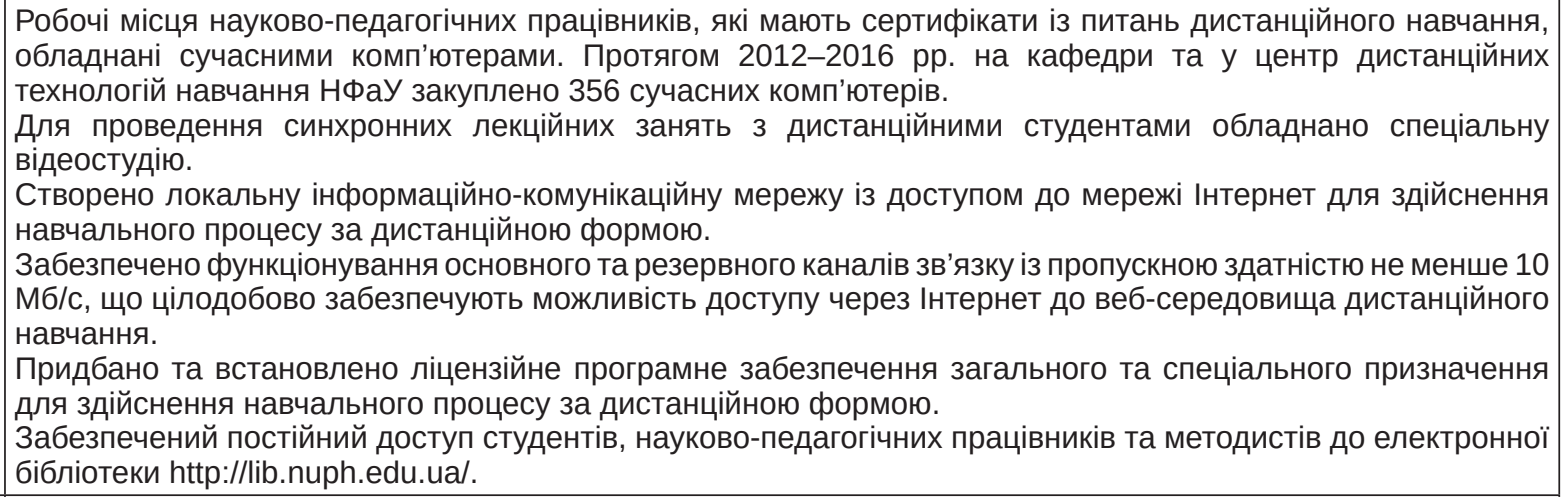 \\
\hline 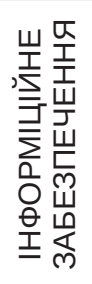 & $\begin{array}{l}\text { el.kharkiv.edu/moodle/, який забезпечує } \\
\text { додо роботи з дистанційними курсами, } \\
\text { нційних курсів окремих дисциплін, г) сервісів, } \\
\text { крема Google Hangouts, д) системи управління } \\
\text { ня. } \\
\text { ють навчальний план спеціальності } 226 \\
\text { добутого освітньо-кваліфрікаційного рівня }\end{array}$ \\
\hline
\end{tabular}

Як свідчать дані, наведені в таблиці 2, відповідність вимогам МОН України щодо впровадження дистанційного навчання націлює ВНЗ на принципову модернізацію як матеріально-технічного забезпечення, так і педагогічних технології навчання й професійної майстерності викладачів.

Отже, ми повністю розділяємо думку фрахівців Сумського державного, Хмельницького національного та Чернігівського національного технологічного університетів, лідерів дистанційної освіти в Україні, що впровадження цієї форми навчання відповідно до нормативно-правових вимог є складним, тривалим та високопрофесійним процесом та потребує значних обсягів фрінансування та відповідного кадрового потенціалу [9].

щодо окремих етапів реалізації Національним фрармацевтичним університетом (м. Харків) вимог нормативно-правової бази з впровадження дистанційного навчання, то їх можна представити наступним чином:

1 етап: 2007-2012 рр. - створення Центру дистанційних технологій навчання, набуття членства уні-

ISSN 2312-0967. Фармацевтичний часопис. 2017. № 3 
верситету в мережі УРАН, підготовка електронних підручників, інших електронних навчально-методичних матеріалів та розміщення їх на сайті дистанційного навчання, платорормою якого обрано Moodle http://pharmel.kharkiv.edu/moodle/;

2 етап: 2012-2015 рр. - підвищення кваліфрікації науково-педагогічних працівників із питань організації та використання дистанційних технологій у навчальному процесі на базі Національного технічного університету «КП|» та Національного технічного університету «ХП|», забезпечення кафредр університету комп'ютерним та периферійним обладнанням для здійснення дистанційного навчання, розробка дистанційних курсів із певних дисциплін спеціальності «Фармація», запис аудіоматеріалів для проведення лекційних та семінарських занять, підготовка відеопрактикумів, які демонструють хімічні та біологічні досліди, технологічні процеси;

3 етап: починаючи 3 2015/2016 н.р. - здійснення набору студентів для участі в педагогічному експерименті з впровадження дистанційного навчання [10].

Для проведення педагогічного експерименту запропоновано методологічні засади дистанційного навчання, які мають принципові відмінності від традиційних фрорм навчання у ВНЗ. Вони полягають у наступному: 1) вивчення однієї дисципліни здійснювалося протягом певної кількості тижнів (від двох до п'яти), тобто використовувалася технологія концентрованого навчання; 2) навчальні програми дисциплін були диференційовано розподілені на дистанційну та очну частину; 3) щонайменш один раз на тиж- день проводили синхронні лекційні заняття; 4) практичні та семінарські заняття здійснювалися у форматі виконання індивідуальних завдань або у фрорматі тематичних фрорумів; 5) супроводження дистанційного курсу передбачало ведення журналу обліку електронних робіт студентів, у якому фріксували дату та час пересилання певної роботи на сайт дистанційного навчання; 6) поточний та проміжний контроль проводився у фрорматі тестування; 7) весь час дистанційні курси супроводжували викладачі (тьютори), спілкування відбувалося у фрорумі «Допомога тьютора», при цьому затримка у повідомленнях зі студентами не перебільшувала 24 год; 8) за роботу у певному дистанційному курсі студент отримував від 36 до 60 балів, що було допуском до очної сесії; 9) лабораторні роботи та здача усіх підсумкових модульних контролів здійснювалися виключно під час очної сесії [11].

У 2015/2016 н.р. у педагогічному експерименті 3 впровадження дистанційного навчання взяли участь 34 особи, які мали освітньо-кваліфікаційний рівень спеціаліст за спеціальністю «Фармація». У лютому 2017 р. вони вже отримали дипломи магістрів. У 2016/2017 н.р. до експерименту залучилися ще 29 осіб. У освітньому процесі були задіяні 17 кафедр університету.

Фрагмент графріку навчального процесу здобувачів вищої освіти, які навчалися за спеціальністю 226 «Фармація», другий (магістерський) рівень, на базі раніше здобутого освітньо-кваліфікаційного рівня спеціаліст, за дистанційною формою наведено у таблиці 3.

Таблиця 3. Фрагмент грасріку навчального процесу (весняний семестр) на 2016/2017 н.р.

\begin{tabular}{|c|c|c|c|c|}
\hline Дисципліна & $\begin{array}{c}\text { Загальна кількість } \\
\text { контактних годин, } \\
\text { зокрема лекцій/ } \\
\text { практичних занять/ } \\
\text { семінарських занять }\end{array}$ & $\begin{array}{c}\text { Дистанційне } \\
\text { навчання } \\
\text { Лекції/практичні } \\
\text { заняття/ } \\
\text { семінарські } \\
\text { заняття }\end{array}$ & $\begin{array}{c}\text { Тривалість } \\
\text { дистанційного } \\
\text { курсу }\end{array}$ & $\begin{array}{c}\text { Очна навчальна } \\
\text { сесія } \\
\text { 07.06.17-11.06.17 } \\
\text { Лекції/практичні } \\
\text { заняття /семінарські } \\
\text { заняття }\end{array}$ \\
\hline $\begin{array}{l}\text { Соціальна економіка у } \\
\text { фрармації }\end{array}$ & $6 / 16 / 16$ & $6 / 12 / 16$ & $\begin{array}{l}\text { 09.01.17-12.02.17 } \\
5 \text { тижнів }\end{array}$ & $-\mid / 4 /-$ \\
\hline $\begin{array}{c}\text { Технологія гомеопатичних } \\
\text { лікарських засобів (вибіркова) }\end{array}$ & $2 /-/ 8$ & $2 /-/ 6$ & $\begin{array}{c}\text { 13.02.17-26.02.17 } \\
2 \text { тижні } \\
\end{array}$ & $-/-/ 2$ \\
\hline $\begin{array}{c}\text { Державна система } \\
\text { забезпечення якості } \\
\text { лікарських засобів (вибіркова) }\end{array}$ & $2 /-/ 8$ & $2 /-/ 6$ & $\begin{array}{l}27.02 .17-12.03 .17 \\
2 \text { тижні }\end{array}$ & $-/-/ 2$ \\
\hline Психологія спілкування & $6 /-/ 6$ & $6 /-/ 4$ & $\begin{array}{c}\text { 13.03.17-26.03.17 } \\
2 \text { тижні } \\
\end{array}$ & $-/-/ 2$ \\
\hline $\begin{array}{c}\text { Розробка та валідація методів } \\
\text { контролю якості лікарських } \\
\text { засобів }\end{array}$ & $6 / 16 / 16$ & $6 /-/ 16$ & $\begin{array}{c}27.03 .17-16.04 .17 \\
\text { 3 тижні }\end{array}$ & $-/ 16 /-$ \\
\hline Клінічна фрармакологія & $6 / 16 / 16$ & $6 /-/ 16$ & $\begin{array}{c}\text { 17.04.17-07.05.17 } \\
\text { 3 тижні } \\
\end{array}$ & $-/ 16 /-$ \\
\hline $\begin{array}{c}\text { Мікробіологічна безпека } \\
\text { лікарських засобів (вибіркова) }\end{array}$ & $2 /-/ 8$ & $2 /-/ 6$ & $\begin{array}{c}\text { 08.05.17-21.05.17 } \\
2 \text { тижні }\end{array}$ & $-/-/ 2$ \\
\hline $\begin{array}{c}\text { Підготовка фрармацевтичного } \\
\text { працівника (вибіркова) }\end{array}$ & $2 /-/ 8$ & $2 /-/ 6$ & $\begin{array}{c}22.05 .17-04.06 .17 \\
2 \text { тижні }\end{array}$ & $-/-/ 2$ \\
\hline PA30M & $32 / 48 / 86$ & $32 / 12 / 76$ & & $0 / 36 / 10$ \\
\hline
\end{tabular}

ISSN 2312-0967. Pharmaceutical review. 2017. № 3 
Отже, запропоновані та опрацьовані під час педагогічного експерименту методологічні засади дистанційного навчання забезпечують прозорість та постійний контроль як за освітньою діяльністю здобувачів вищої освіти, так і за її супроводженням із боку тьюторів.

Висновки. 1. На прикладі Національного фрармацевтичного університету (м. Харків) визначено послідовність етапів та заходи щодо виконання вимог діючих нормативно-правових документів МОН України з впровадження дистанційного навчання.
2. Запропоновано методологічні засади дистанційного навчання, які мають принципові відмінності від традиційних форм (денної та заочної) та забезпечують прозорість і постійний контроль за освітньою діяльністю студентів.

3. Досвід із впровадження дистанційного навчання у Національному фрармацевтичному університеті (м. Харків) може бути використаний іншими ВН3, які забезпечують підготовку спеціалістів фрармації.

4. Перспективами наших подальших досліджень стане аналіз та узагальнення результатів проведеного педагогічного експерименту.

\title{
ВНЕДРЕНИЕ ДИСТАНЦИОННОЙ ФОРМЫ ОБУЧЕНИЯ В ФАРМАЦЕВТИЧЕСКОЕ ОБРАЗОВАНИЕ (НА ПРИМЕРЕ НАЦИОНАЛЬНОГО ФАРМАЦЕВТИЧЕСКОГО УНИВЕРСИТЕТА)
}

\section{л. В. Галий, т. Н. Серопян}

Национальный фрармацевтический университет, Харьков

larisa_galiy@ukr.net

Цель работы. Обобщение требований нормативно-правовых документов МОН Украины и определение методологических основ внедрения дистанционного обучения в фармацевтическое образование.

Материалы и методы. Системный метод, сравнительный и нормативно-правовой анализ, метод педагогического эксперимента.

Результаты и обсуждение. На примере Национального фрармацевтического университета (г. Харьков) обобщены этапы и мероприятия по выполнению требований нормативно-правовых документов МОН Украины по внедрению дистанционного обучения. Описано организационное, научно-методическое, кадровое, материально-техническое и инорормационное обеспечение университета. На основе предложенных авторами методологических основ дистанционного обучения составлен график учебного процесса и осуществлена координация педагогического эксперимента, в котором приняли участие 63 студента и 17 кафедр университета.

Выводы. Предложенные и апробированные во время педагогического эксперимента методологические основы дистанционного обучения обеспечивают прозрачность и постоянный контроль как за образовательной деятельностью студентов, так и за ее сопровождением со стороны тьюторов. Опыт внедрения дистанционного обучения в Национальном фрармацевтическом университете (г. Харьков) может быть использован вузами, которые осуществляют подготовку специалистов фрармации.

Ключевые слова: дистанционное обучение; фрармацевтическое образование; тьютор; педагогический эксперимент.

\section{IMPLEMENTATION OF DISTANCE LEARNING IN PHARMACEUTICAL EDUCATION (ON EXAMPLE OF NATIONAL UNIVERSITY OF PHARMACY)}

\author{
L. V. Galiy, T. M. Seropian \\ National University of Pharmacy, Kharkiv \\ larisa_galiy@ukr.net
}

The aim of the work. Generalization of the requirements of the Ministry of Education and Science of Ukraine legal documents and determination of the methodological foundations of distance learning implementation in pharmaceutical education.

Materials and Methods. Systemic method, comparative and legal analysis, method of pedagogical experiment.

Results and Discussion. On the example of National University of Pharmacy (Kharkiv) the phases and activities to meet the requirements of legal documents of the Ministry of Education and Science of Ukraine for the implementation of distance learning have been summarized. Organizational, scientific-methodological, personnel, material, technical and informational supports of the university have been described. Based on the methodological foundations of distance learning offered by the authors, a schedule of the educational process was drawn up and the coordination of the pedagogical experiment was coordinated, in which 63 students and 17 departments of the university took part.

ISSN 2312-0967. Фармацевтичний часопис. 2017. № 3 
Conclusions. The methodological foundations of distance learning offered and tested during the pedagogical experiment provide transparency and constant monitoring both for the educational activities of students and for its accompaniment by tutors. The experience of distance learning implementation at the National University of pharmacy (Kharkiv) can be used by higher education institutions, which train specialists in pharmacy.

Key words: distance learning; pharmaceutical education; tutor; pedagogical experiment.

\section{Список літератури}

1. Ткаченко Н. О. Вивчення чинників, що впливають на якість підготовки фрармацевтичних фрахівців / Н. О. Ткаченко, Б. П. Громовик // ScienceRise. Pharmaceutical Science. - 2016. - № 2 (2). - С. 36-42.

2. 5-й міжнародний фрармацевтичний фрорум «АПТЕКИ СВІТУ-2016». Аптечний ринок України: головні тренди // Аптека. - 2016. - № 1044 (23). - [Электронный ресурс]. - Режим доступу: http://www.apteka.ua/article/375989.

3. Режим доступу: http://www.distancelearningportal.com/ universities/253/keele-university.html

4. Режим доступу: http://www.mastersportal.eu/studies/56317/clinical-pharmacy.html

5. Режим доступу: http://www.mastersportal.eu/studies/9441/clinical-pharmacy.html

6. Режим доступу: http://pharmacy.ufl.edu/education/online-ms-programs/.

7. Про затвердження Положення про дистанційне навчання: наказ МОН України від 25.04.2013 р. № 466. - [Електронний ресурс]. - Режим доступу: http://zakon2. rada.gov.ua/laws/show/z0703-13.

8. Про затвердження Вимог до вищих навчальних закладів та закладів післядипломної освіти, наукових, освітньо-наукових установ, що надають освітні послуги за дистанційною формою навчання 3 підготовки та підвищення кваліфрікації фрахівців за акредитованими напрямами і спеціальностями: наказ $\mathrm{MOH}$ України від 30.10.2013 р. № 1518. - [Електронний ресурс]. - Режим доступу: http://zakon2.rada.gov.ua/laws/show/z1857-13.

9. Інформаційне, методичне та організаційне забезпечення дистанційного навчання у вищих навчальних закладах України [Текст] : монографрія / [M. П. Мазур [та ін.]] ; Сум. держ. ун-т, Хмельниц. нац. ун-т, Черніг. нац. технол. ун-т. - Суми : СумДУ, 2013. - 151 с. 10. Калинина А. НФаУ реализует авторскую концепцию дистанционного обучения // А. Калинина // Ежедневник Аптека. - 2015. - № 1015 (44). - [Электронный ресурс]. Режим доступу: http://www.apteka.ua/article/351006

11. Галій Л. В. Досвід НФаУ 3 впровадження дистанційної форми навчання: стан, проблеми, перспективи / Л. В. Галій, Т. М. Серопян // Актуальні питання дистанційної освіти та телемедицини 2016: матеріали наук.-метод. відеоконф., м. Запоріжжя, 13 жовтня 2016 р. - Запоріжжя, 2016. - С. 78-80.

\section{References}

1. Tkachenko NO, Hromovyk BP. [The study of factors affecting the quality of pharmaceutical specialists training]. ScienceRise. Pharmaceut Science. 2016;2(2): 36-42. Ukrainian.

2. 5-yi Mizhnarodnyi farmatsevtychnyi forum «APTEKY SVITU-2016». Aptechnyi rynok Ukrainy: holovni trendy [5th International Pharmaceutical Forum "PHARMACY WORLD 2016". Main trends of the pharmaceutical market in Ukraine]. Apteka. Available at: http://www.apteka.ua/article/375989

3. Available at: http://www.distancelearningportal.com/universities/253/keele-university.html

4. Available at: http://www.mastersportal.eu/studies/56317/ clinical-pharmacy.html

5. Available at: http://www.mastersportal.eu/studies/9441/clinical-pharmacy.html

6. Available at: http://pharmacy.ufl.edu/education/onlinems-programs/.

7. Pro zatverdzhennia Polozhennia pro dystantsiine navchannia [On approval of the distance learning]: order of the Ministry of Education and Science of Ukraine from 25.04.2013 p. № 466. Available at: http://zakon2.rada.gov. ua/laws/show/z0703-13.

8. Pro zatverdzhennia vymoh do vyshchykh navchalnykh zakladiv [On approval of requirements to universities and graduate schools, scientific, educational and scientific institutions that provide educational services for distance learning of training and qualification accredited areas and specialties]: order of the Ministry of Education and Science of Ukraine from 30.10.2013 p. № 1518. Available at: http:// zakon2.rada.gov.ua/laws/show/z1857-13.

9. Mazur MP, Zuban YO, Liubchak VO, Ivanets CA. Informational, methodological and organizational support of distance learning in higher education Ukraine. [Інфрормаційне, методичне та організаційне забезпечення дистанційного навчання у вищих навчальних закладах України] Sumy: Sumy State University; 2013. Ukrainian.

10. Kalinina A. [NUPh: The author's concept of distance learning is realized]. Apteka. Available at: http://www.apteka.ua/article/351006

11. Halii LV, Seropian TM. Experience of the implementation of distance learning: state, problems and prospects. Topical issues of distance learning and telemedicine: Proceedings of the Research and Methodical Videoconference Topical issues of distance learning and telemedicine, 2016 Oct 13; Zaporizhzhia: Zaporizhzhia State Medical University; 2016. P. 78-80. Ukrainian. 